\title{
Investigating the Mass Variation of Jute Spun Yarn Produced by Modified Spinning Frame
}

\author{
Md. Khalilur Rahman Khan ${ }^{*}$ \\ Faculty of Engineering \& Applied Sciences, Bangladesh University of Business and Technology, Dhaka, Bangladesh
}

DOI: $10.36348 /$ sjet.2020.v05i11.004 $\quad$ | Received: 19.10.2020 | Accepted: 03.11.2020 | Published: 09.11 .2020

*Corresponding author: Md. Khalilur Rahman Khan

\section{Abstract}

Evenness is one of the main criteria characterizing quality for any staple spun yarn. Variation in yarn mass have significant influences like the other quality parameters of jute spun yarn for being applied in the diversified items. However, jute flyer spinning frame had been modified in the drafting zone to improve the quality parameters of jute yarn. In this study, mass variation (unevenness) results of jute yarn had been investigated by producing two types of jute yarn counts (i.e., 6.5 and $10 \mathrm{lbs} / \mathrm{spy}$ ) for both the existing and the modified spinning frame. Hence, the results of jute yarn unevenness values had been compared between the modified and the existing spinning frame. Results revealed that mass variations of jute spun yarn had been decreased for the modified spinning frame for the both counts (i.e., $6.5 \mathrm{lbs} / \mathrm{spy}$ and $10 \mathrm{lbs} / \mathrm{spy}$ ). Finally, it was remarked that the modified spinning frame produced a better quality of jute yarn in terms of mass variation compared to that of the existing spinning frame.

Keywords: Jute Yarn, Mass Variation, Modification, Spinning Frame.

Copyright (C) 2020 The Author(s): This is an open-access article distributed under the terms of the Creative Commons Attribution 4.0 International License (CC BY-NC 4.0) which permits unrestricted use, distribution, and reproduction in any medium for non-commercial use provided the original author and source are credited.

\section{INTRODUCTION}

Jute industry is one of the oldest industries of Bangladesh and has been continuing to function with large number of age-old machinery and technologies. Now-a-days, diversified jute products are increasing profusely. As a result, production of jute yarn with improved quality is a matter of concern for the spinner. However, the properties of yarn are very important in determining their possible applications [1]. Irregularity is the important quality attribute of a spun yarn that influence the yarn process ability and fabric appearance. The irregularity or unevenness of a yarn is commonly defined as the variation in mass per unit length along the yarn. The irregularity (unevenness) of mass indicates the amount of overall mass variation in \% from the mean mass of the sample tested. It is expressed as $\mathrm{U}_{\mathrm{m}} \%$ or $\mathrm{CV}_{\mathrm{m}} \%[2,3]$. Mass variation in yarn can adversely affect many properties of textile materials such as shade variations and strength [4]. However, irregularity or mass variation of jute spun yarn needs attention because it can be considered as one of the drawbacks for its applications in diversified fields.

A research work had been carried out for the production of jute spun yarn by modification of drafting zone of jute flyer spinning frame [5] destined to make a comparison between the existing frame and the modified frame in terms of yarn quality parameters such as hairiness, strength etc. However, in this study, results of jute yarn unevenness values $\left(\mathrm{CV}_{\mathrm{m}}\right)$ have been investigated by selective modifications of the jute spinning frame and a comparison has been made between the modified spinning frame and the existing frame as well.

\section{MATERIALS AND METHODS \\ Modifications of Jute Spinning Frame}

The major modifications that had been carried out for performing this experiment are as follows:

a) The drawing pressure roller (diameter $=70 \mathrm{~mm}$ $\&$ Durometer hardness $=96$ in Shore A Scale) of the apron draft spinning frame had been substituted by a rubber coated top roller (diameter $=40 \mathrm{~mm} \&$ Durometer hardness $=85$ in Shore A Scale).

b) An extra slotted roller (Diameter $=26 \mathrm{~mm} \mathrm{\&}$ Durometer hardness $=74$ in Shore A Scale) had also been nipped with bottom drawing roller and positioned parallel to the modified top roller (shown in Figure-1).

c) The angle between the slot direction of the slotted roller and the centerline of drafted fiber strand was selected as $45^{\circ}, 60^{\circ} \& 75^{\circ}$ for this experiment. Ultimately, 3 types of 
Md. Khalilur Rahman Khan; Saudi J Eng Technol, Nov, 2020; 5(11): 419-421

modifications of jute spinning frame were made (i.e., Type-B, Type-C and Type-D) respectively whereas the existing spinning frame is denoted by Type-A.

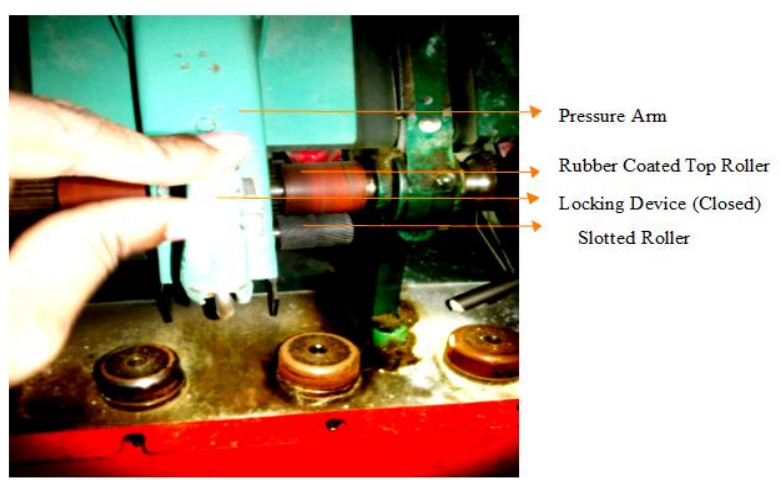

Fig-1: Modified drafting system of jute spinning frame

\section{Yarn sample Preparation}

Jute slivers of $0.69 \mathrm{lbs}$ per 100 yards were produced by using white $\mathrm{B}$ grade jute as raw materials. One breaker card, one finisher card and three consecutive jute drawing frames were used for this experiment. However, bundle fiber strength (g/Tex) of breaker card sliver, finisher card sliver and third drawn sliver were found 35.92, 31.73 and 30.60 respectively measured by Stelometer. Processing parameters of this experiment are given in table-1. Jute yarn counts of 6.5 lbs/spy and $10 \mathrm{lbs} / \mathrm{spy}$ were selected as nominal count for this work. Moreover, nominal twist per meter for 6.5 lbs/spy and $10 \mathrm{lbs} / \mathrm{spy}$ were kept 194.38 and 155.51 respectively.

\section{Testing Procedure}

Before testing of yarn average fineness and unevenness $\left(\mathrm{CV}_{\mathrm{m}}\right)$, every sample had been conditioned in quality room for 48 hours. Wrap reel and electric balance method had been used for measuring jute yarn linear densities. At first, for each sample testing, 25 yards of jute yarn by wrap reel had been measured and then it was weighed by electric balance machine. Finally, jute yarn fineness had been determined by direct system (i.e., lbs/spy). However, Jute yarn mass variation $\left(\mathrm{CV}_{\mathrm{m}}\right)$ were obtained by testing the jute spun yarn on premier evenness tester. Testing speed of evenness tester was kept $25 \mathrm{~m} / \mathrm{min}$.

Table-1: Processing parameters of the experiment

\begin{tabular}{|l|l|l|}
\hline Serial No. & Parameters & Value \\
\hline 1. & Avg. MR\% of breaker card sliver & $17.49 \%$ \\
\hline 2. & Avg. MR\% of Finisher card sliver & $15.96 \%$ \\
\hline 3. & Avg. MR\% of $3^{\text {rd }}$ Drawn sliver & $12.45 \%$ \\
\hline 4. & Twist factor (k-factor) & 12 \\
\hline 5. & Avg. Input sliver weight for spinning frame & $0.69 \mathrm{lbs}$ per 100 yards \\
\hline 6. & Input sliver MR\% & 12.45 \\
\hline 7. & Flyer RPM & 3300 \\
\hline
\end{tabular}

Table-2: Experimental Results of Jute Yarn Irregularity $\left(\mathrm{CV}_{\mathrm{m}}\right)$

\begin{tabular}{|c|c|c|c|c|c|}
\hline \multirow{3}{*}{$\begin{array}{l}\text { Count } \\
\text { (lbs/spy) }\end{array}$} & \multirow{3}{*}{$\begin{array}{l}\text { Yarn Mass Variation } \\
\text { (Irregularity) }\end{array}$} & \multicolumn{4}{|c|}{ Independent Variables } \\
\hline & & Type-A & Type-B & Type-C & Type-D \\
\hline & & $\begin{array}{l}\text { Existing } \\
\text { Frame }\end{array}$ & $\begin{array}{l}\text { Modified With } \\
45^{\circ} \mathrm{S} / \mathrm{R}\end{array}$ & $\begin{array}{l}\text { Modified With } \\
60^{\circ} \mathrm{S} / \mathrm{R}\end{array}$ & $\begin{array}{l}\text { Modified With } \\
75^{\circ} \mathrm{S} / \mathrm{R}\end{array}$ \\
\hline \multirow{6}{*}{$\begin{array}{l}6.5 \\
\text { (lb/spy) }\end{array}$} & \multirow{5}{*}{ Yarn $\mathrm{CV}_{\mathrm{m}}(\%)$} & 30.84 & 30.43 & 29.05 & 26.54 \\
\hline & & 29.46 & 30.45 & 31.07 & 26.47 \\
\hline & & 35.54 & 28.74 & 32.14 & 24.90 \\
\hline & & 32.43 & 29.74 & 29.28 & 24.79 \\
\hline & & 29.22 & 28.61 & 31.64 & 27.39 \\
\hline & Mean & 31.50 & 29.59 & 30.64 & 26.02 \\
\hline \multirow{6}{*}{$\begin{array}{l}10 \\
\text { (lb/spy) }\end{array}$} & \multirow{5}{*}{ Yarn $\mathrm{CV}_{\mathrm{m}}(\%)$} & 34.42 & 27.53 & 30.95 & 32.62 \\
\hline & & 34.96 & 32.54 & 32.35 & 29.16 \\
\hline & & 34.83 & 31.30 & 29.93 & 31.41 \\
\hline & & 33.89 & 30.87 & 35.18 & 29.40 \\
\hline & & 36.18 & 29.34 & 30.97 & 32.11 \\
\hline & Mean & 34.86 & 30.32 & 31.88 & 30.94 \\
\hline
\end{tabular}

\section{RESULTS AND DISCUSSION}

Experimental results summary is given in Table-2. From the obtained results, it is observed that the average jute yarn mass $\mathrm{CVm} \%$ of the existing drafting system of jute spinning frame for yarn count of
6.5 lbs/spyndle is 31.5 while the mass $\mathrm{CVm} \%$ of the modified spinning frame for $6.5 \mathrm{lbs} / \mathrm{spyndle}$ are lies in the range of 26.02 to 30.64 . Among the three types of modifications, modification with $75^{\circ}$ slotted roller has produced better results in terms of yarn evenness. It is worth mentioning that for yarn counts $6.5 \mathrm{lbs} / \mathrm{spyndle}$, 
all three types slotted roller (i.e., $45^{\circ}, 60^{\circ}$ and $75^{\circ}$ ) have created better results in term of yarn evenness in comparison with the existing jute spinning frame. In case of $10 \mathrm{lbs} / \mathrm{spy}$, unevenness value $(\mathrm{CVm} \%)$ results have been decreased by $13.2 \%, 8.5 \%$ and $11.3 \%$ for $45^{\circ}, 60^{\circ}$ and $75^{\circ}$ slotted rollers respectively. Figure- 2 compares the yarn unevenness values of the existing jute spinning frame with yarn unevenness values of the modified spinning frame as well. This trend of improvement in jute yarn unevenness or mass variation can be explained in such a way that grip is always better on the fibers, if we have a relatively softer top roller surface. In the modified system, top roller having
Durometer hardness of 85 in Shore A Scale has been used as a replacement of drawing pressing roller that has Durometer hardness of 96 in Shore A Scale). Comparatively softer type top roller surface completely surrounds the fiber mass. Therefore, fibers get better guidance during drafting action. Ultimately, yarn evenness will be reduced. On the other hand, extra slotted roller has been used after the nip point of the front top roller by which fibers get somewhat tension resulting in better control of edge fiber in friction field of drafting zone. As a result, yarn unevenness has been decreased in general for the modified drafting system.

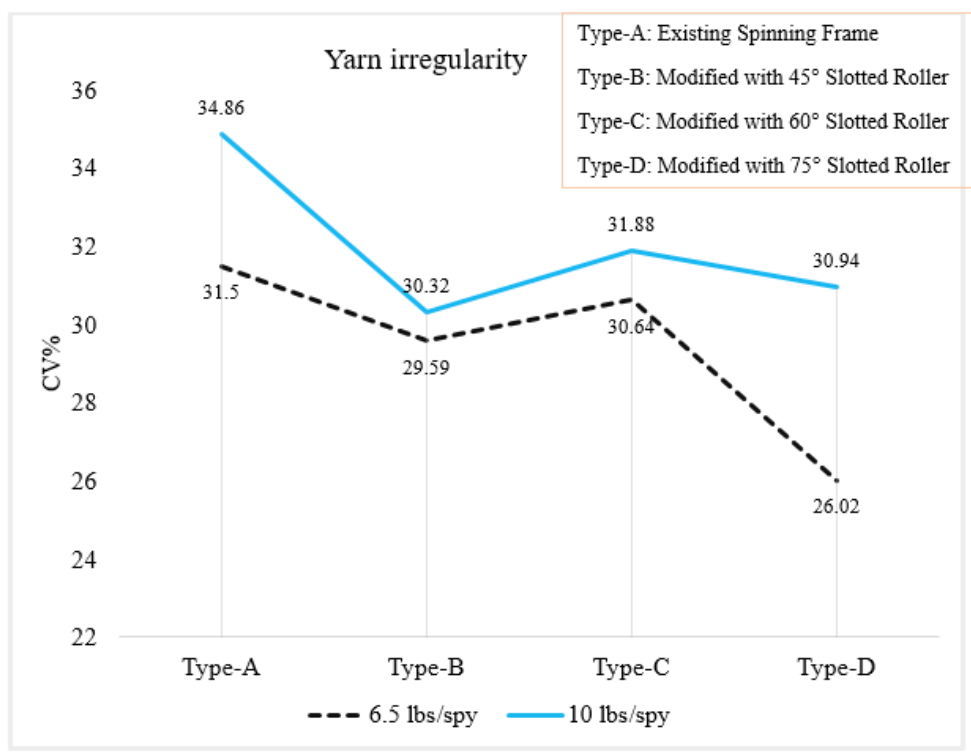

Fig-2: Comparison of yarn mass variation $\left(\mathrm{CV}_{\mathrm{m} \%}\right)$

\section{CONCLUSION}

This study focuses on investigating the effects of modified drafting zone on the results of mass variation of jute spun yarn produced from jute flyer spinning system. Firstly, it is seen that yarn unevenness values $\left(\mathrm{CV}_{\mathrm{m}} \%\right)$ have been decreased for both types of yarn count (i.e. $6.5 \mathrm{lbs} / \mathrm{spy} \& 10 \mathrm{lbs} / \mathrm{spy}$ ). With reference to type of modification, it is seen that jute spinning frame modified with $75^{\circ}$ slotted roller give better results in terms of the yarn irregularity irrespective of yarn fineness of this study. Besides, it is also worth mentioning that other types of modification produce better yarn evenness compared to the existing spinning frame in general. Lastly, it can be concluded that the modified spinning frame improves the yarn evenness that will be resulted in the increasing levels of suitability of the jute spun yarn for being used in many fields. Experimental investigations in this work have been performed by modifying only one head of drafting zone (i.e., two output position) of jute spinning frame that can be considered as a limitation of this study.

\section{REFERENCES}

1. Elshakankery, M., El-Sayed, M., \& Sanad, S. (2008). Method of Predicting the Breaking Load of Egyptian Extra Long Staple Cotton by Using Neural Networks. Journal of Applied Sciences Research, 4(11), 1380-1386.

2. Gowda, R. V. (2003). Irregularity and imperfections in ring-spun yarns. Indian Journal of Fiber and Textile Research, 28, September: 363-366.

3. Khurshid, M. F., Nadeem, K., Asad, M., Chaudhry, M. A., \& Amanullah, M. (2013). Comparative analysis of cotton yarn properties spun on pneumatic compact spinning systems. Fibres \& Textiles in Eastern Europe.

4. Addisu, F., \& Abdul Hameed, P. M. (2007). Investigation into the periodicity of mass variation of yarn and its effect on fabric appearance. AUTEX Res $J, 7(2), 89-94$.

5. Khalilur, R. K., \& Hosne, A. B. (2020). Modification of Drafting Zone of Jute Flyer Spinning Frame to Improve the Jute Yarn Quality, European Scientific Journal (ESJ); 16(27):354. 